\title{
The Subject-Departmentalized Public Library
}

Mr. Maizell is librarian, Research Laboratory, Mathieson Chemical Corporation, Niagara Falls.

$\mathrm{T}$ HERE is no doubt that subject departmentation has become one of the most significant forms of public library organization. Over seven million people live in the areas served by the nine public libraries which are organized entirely on the basis of subject departments. Many millions more live in the areas served by additional public libraries which have at least one subject department each. Since 1924, with the notable exception of Philadelphia, virtually every major public library building erected in this country has been very largely or entirely a subject-departmentalized library.

The purposes of this study are to clarify the meaning of subject departmentation, to summarize its historical development, to indicate the problems involved in the plan, and to develop a body of principles for the guidance of administrators of subject-departmentalized libraries. Although it is primarily concerned with public libraries, the discussion has relevance to the academic library as well. In the preparation of this study, the first step was to survey the literature on the topic, including annual reports of departmentalized libraries. The writings of Barton, McDiarmid, Martin and Phelps should be mentioned as being especially noteworthy. ${ }^{1}$ On the basis of this

1 See the following:

Barton, M. "Administrative Problems in Reference Work." In The Reference Function of the Library, p. survey it was possible to gain some idea of the historical development of subject departmentation. It was also possible to construct a checklist of what appeared to be the major problems and principles involved in subject departmentation. The checklist was submitted in the form of a rating sheet to a group of librarians now working in departmentalized libraries in order to secure their judgments as to the importance of the problems and the validity of the principles. A total of 53 replies was received from the top administrators and subject department heads in five departmentalized libraries: Brooklyn, Cleveland, Enoch Pratt of Baltimore, Los Angeles and Toledo.

\section{The Meaning of Subject Departmentation}

Before defining what is meant by subject departmentation, it may be well to enumerate the several major kinds of public library organization which exist today.

Libraries with very few or no subject departments and with a major distinction between circulating and reference materials. This is known as the functional type of organization and is exemplified by the St. Louis Public Library.

2. Libraries with several subject departments and with the distinction between circu-

218-33. Chicago, University of Chicago Press, 1943.

McDiarmid, E. W., and McDiarmid, J. The $\mathrm{Ad}$ ministration of the American Public Library. Chicago, American Library Association, 1943, p.69-143.

Los Angeles, Bureau of Budget and Efficiency Or. ganization... of the Los Angeles Public Library. Los ganization .8 of the

Angeles, I948-49. 6v.

Phelps, R. B. "The Effects of Organizational Patterns on Reference Work ..." Ph.D. dissertation, University of Chicago, Graduate Library School, I943. Typewritten. 
lating and reference materials less clear than in the first type mentioned. This is known as the partial or mixed type of departmental organization. An example is the Boston Public Library.

3. Libraries with many subject departments and with only a few fields of knowledge remaining not departmentalized. This type of library is in a stage of transition toward complete departmentation. An example is the Detroit Public Library.

(4) Completely departmentalized libraries. This type is organized entirely on the basis of subject departments and is the only type correctly referred to as the subject-departmentalized library. Examples are Brooklyn, Cleveland and Los Angeles. It is this type with which this study is concerned.

The distinctions made above, though clearly not of a hairline nature, are important and should be borne in mind. We may now describe the subject-departmentalized library more fully as one which consists of a number of subject departments, each of which covers a major segment of the recorded knowledge of mankind; contains both circulating and reference materials of all kinds within this segment of knowledge; and is staffed, in an ideal situation, by a group of librarians who are well versed in the literature of the subjects contained in the department. It should be readily apparent that the plan is similar to the departmentalized arrangement in many university libraries. The major points of difference are that in the public library there are fewer departments (perhaps six or seven) and these are in a central building rather than being dispersed about a campus. Nevertheless, many of the problems and principles involved should be the same.

\section{The History of Subject Departmentation}

The roots of public library subject departmentation extend surprisingly far down into American library history; in fact, its origin may be traced as far back as the lat- ter part of the nineteenth century. The early growth of subject departmentation may be attributed to a variety of influences. One of these was the development of college and university libraries in the latter part of the last century. Another influence was the presence of previously existing forms of public library departmentation, such as reference and circulation departments and children's rooms. This meant that libraries had by now grown sufficiently large and complex to warrant division of labor and specialization. The presence of certain special collections which could be developed into subject departments was a third factor. A fourth influence was the emergence of clearly defined community interest groups which seemed to need special services. Thus, the first subject departments were usually in the areas of music, art, business or technology.

William F. Poole, who is best remembered today for his index of nineteenthcentury periodical literature, is usually given credit for the origin of the idea of subject departmentation. His ideas on the subject were first expressed in a very tentative form in $1876,{ }^{2}$ matured slowly over a period of years, ${ }^{3}$ and ultimately found full realization with the completion of the $\mathrm{New}$ berry Library building in Chicago in 1893 .

Perhaps the first individual subject departments to appear in a large public library were in the Boston Public Library. In its new building, which was occupied in 1895 , Boston had introduced a special libraries floor with a fine arts department and an industrial arts department. Later in 1898 , Librarian Herbert Putnam established a Department of Documents and Statistics whose stated functions were very similar to those of the modern subject de-

2 Poole, W. F. [Comments] Library Journal, I:125, 1876.

. "The Construction of Library Buildings." Library Journal, 6:69-77, April 1881 . 
partment. ${ }^{4}$ In 1900 the Providence Public Library, under the guidance of William E. Foster, also opened a special library floor with an industrial library, an art library and a music library. ${ }^{5}$

While all of the advances mentioned so far are important, they represent relatively immature forms of subject departmentation. There is no evidence in the writings of most of the founders of the early departmentalized libraries that they could foresee the development of many of the activities and advantages of subject departmentation, which appeared naturally after the opening of these libraries and which began to be mentioned in the annual reports. and other publications. Such advantages included the development of staff proficiency in limited subject areas, more effective book selection, easy detection of gaps in the collection and facilitation of special services to groups. Instead, these early thinkers were preoccupied with matters of physical convenience and arrangement; and so long

- as subject departmentation continued to be regarded as a mere grouping together of circulating and reference books on the same subject, further progress could not be expected. To put it more directly, subject departmentation could be exploited fully only if its potentialities-particularly the development of staff subject specialization-were realized, seized upon and developed. This is a generalization which remains true even for today's departmentalized libraries.

To the Cleveland Public Library falls the honor of first carrying the idea of subject departmentation through to its logical conclusion, and thus of becoming the first completely departmentalized public library. As early as $1890^{6}$ Librarian William How-

4 Boston Public Library. Annual Report. 1898 . p. 40 .

5 Foster, W. E. "The Providence Public Library." Library Journal, 25:228-32, May 1900.

6 Brett, W. H. "The Rearrangement of the Cleveland Public Library." Library Journal, $15: 136-7$, May 1890. ard Brett and his staff began mapping out the departmentalized arrangement which went into effect when the library moved into its new temporary quarters in 1913. It was evident almost from the beginning that Brett, unlike others who had previously been interested in subject departmentation, saw clearly the essential nature of the plan and was thus in a good position to take full advantage of it.

Since then, the plan has been adopted with varying modifications by Los Angeles; Baltimore; Rochester; Brooklyn; Toledo; Worcester, Mass.; London, Ont., Can.; and most recently by Washington, D.C. ${ }^{7}$ Special mention should be made of Joseph L. Wheeler who helped introduce the preliminary stages of departmentation in the Los Angeles Public Library, and who later helped develop the Enoch Pratt building. This building, incidentally, is believed to be very satisfactory for subject departmentation, and its open-plan design has since been adopted by other libraries. ${ }^{8}$

In addition, several other libraries are now moving toward complete departmentation. Carl Vitz has recently described Cincinnati's proposed new building and its plan for departmentation. ${ }^{9}$ Detroit is also moving toward complete departmentation but will apparently remain in its present building. It seems safe to predict that within the next 25 years or so a number of other large public libraries will have become completely departmentalized. The pressure of important community groups and interests and the inability to develop book collections adequately under the older forms of organization would appear to be the primary factors impelling a move in this direction.

\footnotetext{
7 Peterson, H. N. "D. C. Reorganizes Divisions." Library Journal, $75: 78-81,92$, Jan. I 5, 1950 ; "All Applaud D.C. Change." Library Journal, $75: 143-6$, Feb. pl, 1950 .

I, I950. 8 Githens, A. "The Complete Development of the Open Plan in the Enoch Pratt Free Library in Baltimore." Library Journal, 58:381-5, May 103.3.

9 Vitz, C. "Real Economy but No Sacrifice." Library Journal, 74:1873-6, Dec. I 5, I 949 .
} 


\section{Problems Involved in Subject Departmentation}

Like any other form of organization, subject departmentation has distinct disadvantages as well as advantages. In a review of the literature on the topic, certain problems were found to occur with some degree of regularity. These seemed to arise mainly from the splitting up of the field of knowledge into separate physical and administrative units. Difficulties may also stem from the fact that a library, organized on the basis of subject departments, may lose some of the advantages of other forms of organization. The problems encountered will vary with the subject department and are often directly related to the building layout or to the availability of funds.

It is obvious that subject departmentation should not be adopted merely because it seems to be fashionable at the moment, but rather on the basis of such factors as a clearly demonstrated need for this form of organization and feasibility in terms of availability of personnel, financial resources and suitable physical plant. This word of caution is directed particularly at smaller libraries which may be considering the plan, and to those larger libraries which may not have good financial prospects. It should be realized that subject departmentation brings with it an increased number of service stations and usually an increased volume of service, both of which may place a strain on the library's human and fiscal resources. ${ }^{10}$ In such cases it may be wise to introduce only such subject departments as seem to be warranted by the needs of the community.

In an attempt to determine the reactions of those now working in departmentalized

10 For example, see Los Angeles. Bureau of Budget and Efficiency. op.cit., I:62. It is the contention of that report that the Los Angeles Public Library taxed itself unduly by the introduction and retention of a large number of subject departments. libraries to the problems described in the literature on the subject, the rating sheet mentioned at the beginning of this paper was submitted to the group of 53 librarians in five libraries. The results indicate that the respondents feel that while those problems which do occur are not overly serious, subject departmentation has definite faults fwhich bear watching, especially in newly idepartmentalized libraries. A breakdown of the replies of the five participating institutions showed very few points of agreement. The seriousness of the problems fluctuated from library to library evidently due to the large number of variables involved. Both the literature and the replies on the rating sheets give evidence that those now working in departmentalized libraries have enthusiasm for and confidence in their form of organization.

\section{Problems}

Below is a listing of the 12 problems most commonly met in subject departmentation as ranked in order of importance according to the votes of the participating librarians. Problems ranked from one through nine were thought to be of moderate importance. The remaining three problems were thought by most respondents to be of negligible importance, but should, nevertheless, not be disregarded since mention was made in the literature. A few interpretative comments are supplied in parentheses.

I. The classification of books of interest to several departments.

2. Personnel may lack knowledge of related material in other departments. (This is particularly true of newcomers.)

3. Recruiting of a properly qualified staff. (This is especially difficult for science departments.)

4. Handling of reference questions which cut across the interests of several departments. 5. Coordination of the activities of the subject departments. 
6. Departments may assume excessively self-sufficient attitude and hence will not use related material elsewhere. (This means that departments may tend to become compartments.)

7. Coordination of the work of the catalog department with the needs of the subject departments.

8. Shunting of readers from department to department, especially when a difficult reference question is involved.

9. Subjects falling between departments may be slighted in book selection.

Io. Undue variation of departments in policies and quality of service.

I I. Specialist may be favored at expense of nonspecialist or layman. (While the literature frequently claimed that the layman was placed at a disadvantage by subject departmentation, most respondents thought that this was not the case.) ${ }^{11}$

12. Increased volume of public demand may result, thus placing a strain on the library. (This applies particularly to smaller institutions.)

\section{Principles}

Subject departmentation is not a selfoperating, self-adjusting form of organization. In order to take full advantage of the plan, most departmentalized libraries have found it desirable to follow certain basic operational and administrative principles. A study of the annual reports of several of the departmentalized libraries over a period of years reveals an increasing realization of the need for coordination and cooperation among departments. This is in contrast to the attitude of departmental self-sufficiency which frequently appears shortly after subject departmentation has been first introduced in particular libraries.

The search of the literature revealed 16 principles which are now in actual operation or which have been suggested as possible future developments of value. The response of the 53 librarians to most of the principles

11 For a strong statement of the problem see: Stanley Jast. The Library and the Community. London, Nelson, 1939. p.84. was enthusiastic. One person commented hopefully that "it would be Utopia if all these principles were followed." Further, there was considerable agreement among the votes of the participating libraries. An especially heavy affirmative vote was given to those principles which tended to promote unity and cooperation.

The principles are listed below in the order in which they were ranked by the votes of the respondents. Those principles ranked from one through eleven can probably be safely followed by any departmentalized library, at least as far as can be judged from the vote given these principles. Principles ranked from twelve through sixteen received, on the whole, what were equivalent to negative or unfavorable votes. However, mention in the literature, as well as the presence of some favorable votes, seems to indicate that these principles are not without value and are at least worthy of consideration.

I. Strategically located information desk for the guidance of readers.

2. Departments should be uniform in policies and in quality of service as far as possible.

3. Related departments located on the same floor and adjacent to one another.

4. Departmental catalogs with references to related material in other departments.

5. Person in charge of main building for coordinating purposes.

6. Frequent meetings of subject department heads.

7. Staff knowledge of related material in other departments. (This should lessen the need for duplication of materials and should improve reference service.)

8. If staff has knowledge of the literature of the subjects in their departments, they need not necessarily be subject specialists. (Ideally, both qualities are needed.)

9. Grouping of related departments into larger divisions, such as Sciences, Social Sciences, etc., for improving coordination. (This is similar to the divisional plan of some university libraries. Worcester is the only pub- 
lic library known to be using the plan.)

Io. Occasional rotation of personnel among related departments. (Primarily desirable for newcomers to the library.)

II. Use of the popular library to provide improved service to laymen. (The popular library consists of a carefully selected group of fiction and nonfiction books covering all fields of knowledge and is somewhat akin to a college browsing room.)

I2. Choosing of subject department heads for subject and bibliographical knowledge primarily and for administrative ability only secondarily. (Many respondents felt both qualities were needed.)

13. Five professional staff members for an average department. (Too many variables entered into the picture to offer this as a valid figure, but it may well represent a minimum for a larger library.)

I4. Use of general reference department as a coordinating device. (The low vote here was due to the fact that Brooklyn and Los Angeles have no such department at all but have absorbed its functions into one of the subject departments. Cincinnati is planning to do the same in its proposed new building.)

I5. Shelving books where of most value to readers rather than according to a formal classification scheme. (An example of this idea is the so-called reader interest plan developed by Ralph Ulveling at the Detroit Public Library.)

I6. Subject departments performing own cataloging under central supervision. (This is the concept of decentralized cataloging and was suggested here as a possible future development of value. It was frowned upon by the respondents, most of whom were fearful of the expense and work-load involved.)

\section{Conclusion}

It is hard to say whether subject departmentation represents the ultimate in public library organization, but it is noteworthy that no other important form of public library organization has developed during the past 40 years. Departmentalized college and university libraries have much in common with this form of organization; a mutual exchange of ideas and experiences might be helpful both in avoiding mistakes and in paving the way for future advances. Academic libraries would appear to be equally as susceptible to most of the pitfalls listed in the section on "Problems" as are public libraries; some of them, for example, have already experienced the perils of an excessively large number of independent departmental libraries. The section on "Principles" also seems to be applicable to the academic library. The divisional library (Principle 9) is an example of an idea which seems to have been first hinted at by the subject-departmentalized public library, was then fully developed by a university librarian, ${ }^{12}$ and is now being considered again by some public librarians. This is an idea with numerous ramifications and possibilities and would seem to be one of the most fruitful avenues for the process of joint exploration suggested above.

12 Ellsworth, R. E. “Colorado University's Divisional Reading Room Plan . "College and Research Libraries, 2:103-9, 192, March 1941. 